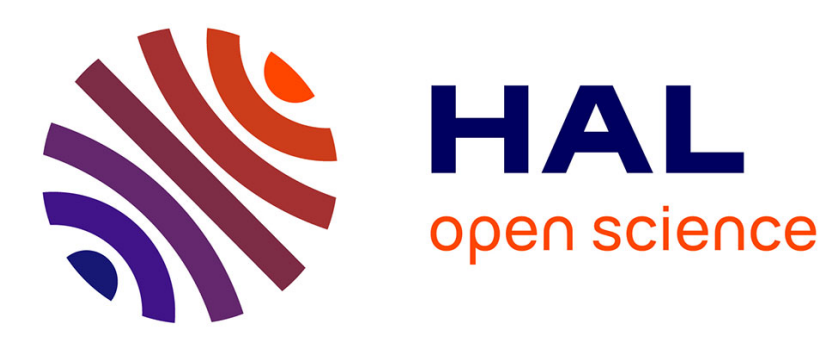

\title{
Anticipative interlocutive dialogism: Sequential patternsand linguistic markers in French
}

\author{
Jacques Bres, Aleksandra Nowakowska, Jean Marc Sarale
}

\section{To cite this version:}

Jacques Bres, Aleksandra Nowakowska, Jean Marc Sarale. Anticipative interlocutive dialogism: Sequential patternsand linguistic markers in French. Journal of Pragmatics, 2016, 96 pp.80-95. hal01338265

\section{HAL Id: hal-01338265 \\ https://hal.science/hal-01338265}

Submitted on 27 Jun 2018

HAL is a multi-disciplinary open access archive for the deposit and dissemination of scientific research documents, whether they are published or not. The documents may come from teaching and research institutions in France or abroad, or from public or private research centers.
L'archive ouverte pluridisciplinaire HAL, est destinée au dépôt et à la diffusion de documents scientifiques de niveau recherche, publiés ou non, émanant des établissements d'enseignement et de recherche français ou étrangers, des laboratoires publics ou privés. 


\section{Jacques Bres, Aleksandra Nowakowska, Jean-Marc Sarale, Praxiling, UMR 5267 CNRS, Université Paul-Valéry Montpellier}

Anticipative interlocutive dialogism: sequential patterns and linguistic markers in French.

\section{Introduction}

The notion of dialogism can be defined as the orientation of discourse towards other instances of discourse. This notion takes root in the works of Russian semiotician Mikhail Bakhtin (1895-1975) and his circle ${ }^{1}$ : Valentin Voloshinov (1895-1936) and Pavel Medvedev (1892-1938). The writings of the Bakhtin Circle - among which Bakhtin's Problems of Dostoevsky's Art (1929), Rabelais and His World (1965), The Aesthetics of Verbal Art (1979), Speech Genres and Other Late Essays (1986); Medvedev's The Formal Method in Literary Scholarship (1928); and Voloshinov's Marxism and the Philosophy of Language (1929) - deal with literary theory, sociolinguistics and the philosophy of language (see the Bakhtin Centre, University of Sheffield). In these research fields have flourished many concepts coined by the Bakhtin Circle - such as carnivalesque, chronotope, dialogism, heteroglossia and polyphony.

From the common viewpoint of the Bakhtin Circle, linguistic production is essentially dialogic because it is formed in the process of social interaction; the dynamics of speech rely on the interaction of different values which are expressed through borrowings or echoes from the speech of others.

The notion of dialogism has received wide attention from contemporary linguists. For instance, dialogism and polyphony ${ }^{2}$ have been used by French linguists to describe the interplay of voices (Authier 1982) or of viewpoints (Ducrot 1984) within the talk and consciousness of a single speaker (see also, in English, Schwenter 2000, Traugott 2009). Goodwin 2007 discussed the models for reported speech and the speaker developed by Volosinov 1929, in order to "disentangle the different voices within a single strip of talk" (p. 37). Goodwin's further aim was to "expand such analysis to incorporate genuine multi-party interaction within the organization of the utterance, and to explore, as an alternative to quotation, sequential practices for assimilating another's talk into a current utterance" (ibid.).

In his research, Mikhail Bakhtin focuses on a specific dialogic relationship - the speaker's anticipation of his/her recipient's response. In other words, as a speaker progresses through his/her own speech, he/she imagines the discursive reactions of his/her recipient (1986:97). He/she interacts

\footnotetext{
${ }^{1}$ Although the issue has been thoroughly discussed (Sériot 2007, Bronckart et Bota 2011, Zenkine 2011, Velmezova 2012), it remains unclear to what extent Voloshinov and Medvedev must be credited with early works published under the name of Bakhtin (and vice versa). This is the reason why we shall attribute some of these works to the Bakhtin Circle, without any further specification.

${ }^{2}$ The distinction between dialogism and polyphony is discussed in XXXX 2005, and XXXX 2007
} 
dialogically with these reactions in order firstly to reply in advance to questions and objections the recipient might formulate and secondly to rectify any fallacious conclusions that he/she might draw.

The purpose of the present article is to analyse the linguistic mechanisms of this anticipation of the recipient's response, corresponding to a particular type of dialogic relationship, which we call anticipative interlocutive dialogism. Our main goal is to describe the discourse structures and the linguistic markers through which anticipative interlocutive dialogism is realised. To the best of our knowledge, this dialogic relationship has not yet been the object of any systematic study.

In the first section of this paper we explain our theoretical framework and methodology, following three consecutive steps: definition of the three components of "anticipative interlocutive dialogism" (1.1.), presentation of our methodology and data (1.2.), introduction of a sequential pattern (1.3.).

Sections 2 to 4 are subsequently devoted to a detailed analysis of three linguistic forms of anticipative interlocutive dialogism: i.e. prolepsis (section 2), integration (section 3) and ellipsis (section 4). In the final section, we will synthetise and discuss our main results (section 5), before attempting to link anticipative interlocutive dialogism to other types of dialogism and discuss its specificity (conclusion).

\section{Theoretical framework and methodology}

\subsection{On anticipative interlocutive dialogism}

In order to characterize anticipative interlocutive dialogism, we will first explain what we mean when we use the words: dialogism, interlocutive (dialogism) and anticipative (interlocutive dialogism).

\subsubsection{Dialogism}

The Bakhtin Circle research has revealed that discourse consists of "dialogue" in the double form of:

- external dialogue, marked by alternating speech turns of different speakers. This is the dialogal dimension that conversational analysis describes in its complexity (management of speech turns, transitional, phatic places, regulators, etc.);

- internal dialogue or dialogic dimension: when one single speaker, within his/her speech turn, or more widely speaking within his/her discourse, interacts with one or several other discourses.

It is this second dimension that is included in the notion of dialogism. Unlike the dialogal dimension which only affects dialogal genres (for instance conversation), this dialogic dimension relates to dialogal genres as well as monologal genres (for example press article, novel, philosophical essay, etc.).

Bakhtin does not suggest any precise linguistic definition of dialogism. Relying on evidence from Russian texts (XXXX 2005), we can say that it consists of the orientation of any discourse (regardless of its format: speech turn of conversation, press article, political discourse, scientific article, etc.) towards other instances of discourse, from a triple viewpoint:

(i) towards other instances of discourse made previously on the same subject;

(ii) towards the reply the speaker is asking for and which he/she is anticipating; 
(iii) towards the discourse itself inasmuch as the speaker is his/her first recipient in the selfreceiving process.

This triple orientation is performed as an interaction and results in an inner dialogisation, expressed by Bakhtin through different metaphors: "plurality of voices", "resonances" (1952: 301, 308), “echoes" (1952: 301, 308), “dialogical harmonics" (1934: 114; 1952 : 277, 300), "reflections of other people's utterances in my utterance" (1952: 298), that can be found in any discourse from its macrostructure (novel, text, speech, speech turn) to its microstructure (word). The first type of interaction is called interdiscursive dialogism (i); the second, interlocutive dialogism (ii); the third, intralocutive dialogism (iii).

Dialogism can be analysed at a macrotextual level of discourse as well as a microtextual level of utterance. Focusing on the microtextual level of utterance, the present study aims at analyzing a subtype of interlocutive dialogism, anticipative interlocutive dialogism.

\subsubsection{Interlocutive dialogism}

The notion of interlocutive dialogism is deeper than appears at first sight. It indicates first of all that the speaker modulates his/her speech according to the recipient (or the image he/she has of him/her), to the knowledge and to the speech he/she ascribes to him/her, to the purpose at hand, etc. These facts have been abundantly described through rhetorics, sociolinguistics, pragmatics and in conversational analysis under the notion of "recipient design" (Sacks, Schegloff, \& Jefferson, 1974, Günthner 1999; Günthner et al. 2015):

By 'recipient design' we refer to a multitude of respects in which the talk by a party in a conversation is constructed or designed in ways which display an orientation and sensitivity to the particular other(s) who are the co-participants. In our work we have found recipient design to operate with regard to word selection, topic selection, admissibility and ordering sequences (...). (Sacks, Schegloff, \& Jefferson, 1974: 727)

The notion of interlocutive dialogism also takes into account the two following factors:

- the syntax of the utterance can be analysed in its dialogic dimension (Zima, Bröne, Feyaerts \& Sambre 2009; Du Bois 2014) that "encompasses the linguistic, cognitive, and interactional processes involved when speakers selectively reproduce aspects of prior utterances, and when recipients recognize the resulting parallelisms and draw inferences from them" (op. cit.: 359). This dimension is particularly visible in most genres of dialogue, "when one speaker constructs an utterance based on the immediately co-present utterance of a dialogic partner" (ibid.). Let us consider the following occurrence borrowed from Du Bois (2014: 362), presented according to the following diagraph that highlights the parallelism between the speech turns 1 and 3:

$\begin{array}{lccllll}1 \mathrm{JOANNE} ; & \text { it } & \text { 's } & \text { kind of } & \text { like } & \wedge \text { you } & \text { Ken } \\ 3 \mathrm{KEN} ; & \text { that } & \text { 's } & \text { not at }{ }^{\wedge} \text { all } & \text { like } & \text { me } & \text { Joanne }\end{array}$

The syntax of $3 \mathrm{KEN}$ is built after the model of 1 JOANNE ("selection and ordering of pronouns (it: that; me: you), proper names (Ken: Joanne), modifiers (kind of: not at all), identical resonances (like: like; 's': s)"), even if, in the present case, it is to signify a strong discrepancy: "the very parallelism is itself exploited to convey difference, and vocative Joanne (in 3) takes cover as tit for tat while actually dripping with irony" (ibid.).

- the speaker interacts not only with prior utterances but also with the later potential response he/she ascribes to the recipient and whose response he/she relentlessly anticipates:

After all, the utterance of the person to whom I am responding (I agree, I object, I execute, I take under advisement, and so forth) is already at hand, but his response (or responsive understanding) is still 
forthcoming. When constructing my utterance, I try actively to determine this response. Moreover, I try to act in accordance with the response I anticipate, so this anticipated response, in turn, exerts an active influence on my utterance (I parry objections that I foresee, I make all kinds of provisos, and so forth). (Bakhtin M. M. 1952/1979/1986: 95)

These two discursive forms of behavior (trying to guess the addressee's response and acting in accordance with his/her anticipated response) may be found in conversational analysis under the name of recipient design. However the notions of recipient design and interlocutive dialogism differ on the following points:

- the notion of recipient design refers to - as Sacks, Schegloff \& Jefferson 1974 put it - "an orientation and sensitivity to the particular other(s) who are the co-participants" in a talk-ininteraction.

- the notion of interlocutive dialogism means that any discourse, dialogal or monologal, is inherently oriented towards the addressee. In verbal interaction as in all kinds of dialogal speech in general - the addressee is none other than the real co-participants. But in monologal genres of discourse, the addressee is somewhat imagined by the speaker as it can be noticed, in written texts, with regard to the figure of the reader.

Therefore we consider the notion of recipient design as the particular form that interlocutive dialogism takes in talk-in-interaction. As we aim at describing some of the linguistic-patterns of interlocutive dialogism, we don't ignore the dimension of recipient design. But far from relying solely on the sources of talk-in-interaction, we collected data from monologal and dialogal genres as well (see below 1.2.).

\subsubsection{Anticipative interlocutive dialogism}

Our views on anticipation don't differ much from what conversation analysts call projectability or anticipation. We conceive the dynamics of time in speech production as follows: notwithstanding its chronological and measurable dimension, time is also "directional" and "kairotic"; it is a "meaning-implicated time" (Schegloff, Ochs and Thompson 1996 : 20). In talk-in-interaction, "a key element of turn-taking organization is the projectability of possible turn completion in advance of its actual arrival", which may lead to an "anticipatory completion by a co-participant or a terminal overlap - the sort of simultaneous talk produced by another in anticipation of the projected imminent completion of current turn, rather than to precipitate it" (op. cit.: 28-29). Conversation analysts made careful and acute descriptions of projectability and anticipation in turn organization (i. a. Schegloff 1996). But as far as we know, they didn't pay full attention ${ }^{3}$ to the fact that the speaker, as he/she proceeds through his/her speech, tries to foresee the response he/she anticipates from his/her addressee, and answers in advance this anticipated response (e.g. by giving extra information, parrying foreseen objections, making all kinds of provisos, and so forth).

Bakhtin himself did not study how the speaker's orientation to other instances of discourse can be implemented by anticipative interlocutive dialogism.

In a previous research on this topic (XXXX 2005?), we introduced the issue of the speaker's dialogic relationship with "the recipient's anticipated response"; but we haven't systematically studied how this discursive interaction is implemented. That is what we plan to do in this article.

Let us illustrate the anticipative interlocutive dialogism with the following example:

(1) (le scripteur envisage l'avenir de la France, confrontée aux difficultés sociales qu'elle rencontre)

\footnotetext{
${ }^{3}$ Except for Depperman 2014 whose study tackles a specific practice of recipient design: the use of negation in order to constrain interpretations of speaker's actions by the co-participant.
} 
La xénophobie et le racisme feront tâche d'huile. Le terreau sur lequel prospèrent le populisme et l'extrême droite sera renforcé de façon inimaginable. Est-ce de l'exagération? Regardons autour de nous. Dans la plupart des pays de l'Union, des partis populistes et d'extrême droite prolifèrent (...). (Le Monde, 24 mai 2005)

(the writer is considering the future of France, confronted with social difficulties)

Xenophobia and racism will spread like wildfire. The soil on which populism and the far-right ideas prosper will be reinforced unimaginably. Is this overreacting? Let us look around us. In most countries of the Union, populist and far-right wing parties proliferate (...). (daily newspaper)

The question form «Est-ce de l'exagération? » ('Is this overreacting?') implies that the speaker is dialogically debating whether a previous comment that was constructed as: [C'est de l'exagération] ('You are overreacting'/ 'It's an exaggeration') is true or not. We analyze this as the response ascribed by the writer to the reader, when reading the particularly black political situation he has just depicted.

\subsection{Methodology and data}

The current study is part of a broader team-research program focused on the linguistic markers of dialogism in various discourse genres. We gathered a corpus made of:

(i) discourse from the dialogal genres of everyday conversation (1 hour of recordings), radio interviews $\left(1 \frac{1}{2} \mathrm{hrs}\right)$, TV sports live coverage $(1 \mathrm{hr})$ and theatre play (the full text of a comedy from Marivaux, Les Fausses confidences, 1737);

(ii) discourse from monologal genres: 100 press articles (50 from the national newspaper, Le Monde, 20 from the economic daily Les Echos, 30 from two cultural weekly magazines, Telerama and La Gazette), two novels (Les Liaisons dangereuses from Laclos, 1782, and Femmes from Sollers, 1983), and 50 emails sent to the same person by 17 different correspondants (April 2009).

950 dialogic utterances have been collected from this corpus and sorted into 3 types of dialogic interaction: interdiscursive, interlocutive or intralocutive (let us note here that many of the utterances were found to belong to two different types simultaneously, or even to all three in some cases). Interlocutive dialogism was identified in 330 utterances, out of which 175 were analysed as anticipative interlocutive dialogism. That enabled us to design a set of linguistic markers that we could link to the discursive dynamics of anticipative interlocutive dialogism. Then, in order to collect more occurrences of anticipative interlocutive dialogism, we searched the following databases:

- Frantext, a database of French literary, legal, scientific and political texts ranging from the $16^{\text {th }}$ to the $20^{\text {th }}$ century;

- Europresse, a multilingual database of European newspapers and magazines, which includes articles from the 1980's up to the present;

- Google, which provided us with contemporary and mostly non-literary written sources.

This was how we collected 800 discursive occurrences of anticipative interlocutive dialogism, along with their contexts. These utterances belong to the already mentioned speech genres, plus a few others: scientific treatise, (mail) letters, etc. Since our goal was to make clear how anticipative interlocutive dialogism can operate in any kind of discourse, we didn't sort this corpus according to speech genres (see our prospects for future research in the conclusion). The excerpts quoted in this paper mainly come from the written press, for a plain and, hopefully, understandable reason: a written context often seems easier to outline than the context of talk-in-interaction for instance, which involves more dimensions. 


\subsection{A sequential pattern of anticipative interlocutive dialogism}

The responsive speech ascribed by the speaker to the recipient and the ways the speaker reacts to this responsive speech are diverse. The analysis of the 800 collected occurrences of anticipative interlocutive dialogism enabled us to establish the following sequential pattern composed of three successive elements:

[x], speaker's utterance;

[y], utterance ascribed to the recipient by the speaker, in response to $[\mathrm{x}]$;

$[\mathrm{z}]$, speaker's utterance, in response to $[\mathrm{y}]$.

These discursive elements can vary in terms of their formation: from a single word or phrase, to an utterance or sequence of several utterances. As a result of our research, three structures can be distinguished, according to the way element $[\mathrm{y}]$ is treated by the speaker: prolepsis, integration and ellipsis. Sections 2, 3 and 4 of this paper are devoted to analytical descriptions of these structures.

\section{Prolepsis: $[\mathrm{x}] \rightarrow \mathbf{R S}^{4}[y] \rightarrow[z]$}

Prolepsis is a figure of speech in which the speaker interjects a question or raises an objection to his/her own discourse, and then immediately answers this question or objection. In this first type, element $[\mathrm{y}]$ is presented as a reported direct $(2,3)$ or indirect $(4)$ speech:

(2) $[\mathrm{x}]$ on remarque que les Français sont de moins en moins intéressés par les municipales / [y] alors vous me direz Marc d'où vient cette désaffection pour les élections municipales ? [z] alors d'abord ce n'est pas un phénomène nouveau (...) (France Culture, matinale animée par Marc Voinchet, 10 mars 2014)

[x] it can be noted that the French are less and less interested by the municipal elections / [y] so, you will tell me how come they shun municipal elections?[z] so then, it is not a new phenomenon (...) (radio excerpt)

(3) $[\mathrm{x}]$ Reste le grand traumatisme de la Révolution, longtemps vécue par une partie de la droite comme la destruction de l'ordre naturel d'une société reposant sur la religion, les coutumes et traditions. [y] Vieilles lunes, dira-t-on. [z] Pas tant que cela, si l'on veut bien prêter attention à celui qui fut le maître à penser de Nicolas Sarkozy pendant cinq ans (Patrick Buisson). (Le Monde, 17 avril 2013)

[x] There remains the great trauma of the Revolution, long considered by a portion of the right-wing as the destruction of the natural order of a society resting on religion, customs and traditions. [y] Outdated old ideas, many will say. ${ }^{5}$ [z]. Not so much, if we pay attention to who was the spin doctor of Nicolas Sarkozy for five years (Patrick Buisson). (daily newspaper)

(4) (Elections départementales) [x] où sont les programmes ? Tous les partis sont ici logés à la même enseigne. Aucun n'affiche de propositions claires, mémorisables par le citoyen. [y] On objectera que la voix du FN est très puissante sur ses thèmes traditionnels de la défense des intérêts français. [z] Dont acte, mais quel est le rapport avec les fonctions des assemblées départementales? (Les Échos, 11 mars 2015)

(Departmental elections) [x] where are the programs? All the parties are tarred with the same brush. None of them offer clear propositions, which a citizen can remember. [y] There will be objections that the voice of the FN is quite powerful in its traditional themes of the defense of French interests. [z] Duly noted, but what relation has this to the functions of the departmental assemblies? (daily newspaper)

The main verb of the reported speech is prototypically conjugated in the future: the enunciation of [y] is laid as posterior to the time $t_{0}$ of the enunciation of [x]. In a dialogal text (2), the subject of this verb is a $2^{\text {nd }}$ person: the dialogue considers the recipient as the addressee. In a monologal text,

\footnotetext{
${ }^{4}$ Reported Speech.

${ }^{5}$ For greater legibility, we shall put in bold characters the element [y] in section 2 and 3.1.
} 
this is most often the $3^{\text {rd }}$ person of the indefinite pronoun (on - i.e. 'one' in English): the writer, while ascribing an utterance to his/her reader, does not consider him/her as an addressee no more than he/she identifies him/her precisely.

The sequential pattern: $[\mathrm{x}] \rightarrow \mathrm{RS}[\mathrm{y}] \rightarrow[\mathrm{z}]$ realises the figure that rhetorics call prolepsis, which consists most often "in anticipating [or in repeating in advance] an objection which might be encountered" (Fontanier 1821/1977: 410). It will be noted that the element [y], when reported as a direct speech, is (when written) neither in italics nor in quotation marks: as if the writer did not go as far as these typographical marks of enunciative heterogeneity since the said utterance is not borrowed effectively from the recipient but is ascribed to him fictitiously.

\section{Integration: $[\mathrm{x}] \rightarrow\left[\mathrm{z}_{[\mathrm{y}]}\right]$}

The integrative structure results from a syntactic transformation in which one element is incorporated into another. Unlike prolepsis, element $[\mathrm{y}]$ ascribed to the recipient is not reported explicitly. It is integrated into the syntax of element $[\mathrm{z}]$ of the speaker himself, in a dialogic utterance where two voices can be heard: the one ascribed to the recipient and the other of the speaker, as in (1). The sequential pattern is hence realized in the following form: $[\mathrm{x}] \rightarrow\left[\mathrm{z}_{[\mathrm{y}]}\right]$. In the utterance $\left[\mathrm{z}_{[\mathrm{y}]}\right]$, the integration of $[\mathrm{y}]$ in $[\mathrm{z}]$ can be implemented in two distinctive ways: integration by correlation or subordination (3.1.), and integration through a process of amalgamation (3.2.).

\subsection{Integration by correlation or subordination}

[y] can be correlated or subordinated to another element of the syntax of the utterance [z].

\subsubsection{Integration by correlation}

(5) $[\mathrm{x}]$ On nomme épigraphie la science des inscriptions. [...] [ $\left.\mathrm{z}_{[\mathrm{y}]}\right]$ Par science nous entendons non seulement le savoir pratique nécessaire pour déchiffrer les monuments, mais aussi celui, plus important encore et plus difficile à conquérir, qui est indispensable pour interpréter les documents qu'on a lus et en tirer les renseignements qu'ils contiennent. (Artières Ph., Vie et mort de Paul Gény, 2013)

$[x]$ The science of inscriptions is called epigraphy. [...] $\left[z_{[y]}\right]$ By science we mean not only the practical knowledge necessary to decipher the monuments, but also, more important still and more difficult to conquer, that which is indispensable to interpret the documents that we have read and to extract the information contained. (biography)

We analyse the syntagm «le savoir pratique nécessaire pour déchiffrer les monuments » ('the practical knowledge necessary to decipher the monuments') as the form taken by element [y] as an interpretation, ascribed to the recipient, of the previous syntagm «sciences des inscriptions » ('science of the inscriptions') ${ }^{6}$. This element is integrated to the syntax of element $[\mathrm{z}]$ in the form of the first clause of the correlative conjunction "not only... but also...".

This type of structure can also be found in the negation with rectification (6), in certain forms of a pseudo-cleft sentence (7) and of comparison (8):

(6) $[\mathrm{x}] \mathrm{Il}$ faut que vous me protégiez auprès d'eux, $\left[\mathrm{z}_{[\mathrm{y}]}\right]$ non pas comme vous pourriez le croire, pour qu'ils me ménagent; mais au contraire pour qu'ils se déchaînent contre moi. (anonyme, Journal de la Société de 1789, 5 juin 1790)

\footnotetext{
${ }^{6}$ Note that this syntagm can also reflect interdiscursive dialogism. Cf. conclusion infra.
} 
[x] You must protect me against them, $\left[\mathrm{z}_{[\mathrm{y}]}\right]$ not as you might believe, so that they spare me, but on the contrary so that they unleash me. (mail correspondance)

(7) $[\mathrm{x}] \mathrm{Si}$ j'ajourne la communication que je dois vous donner de ce projet, $\left[\mathrm{z}_{[\mathrm{y}]}\right]$ ce n'est pas (comme vous pourriez le penser) parce que je ne me trouve point en mesure de m'expliquer nettement à ce sujet ; c'est par la raison que je ne fixerais pas suffisamment votre attention sur mon travail, si je vous le présentais trop brusquement. (Saint-Simon, Cl., Du système industriel, 1822)

[x] If I put off the communication I must have with you about this project, $\left[z_{[y]}\right]$ it is not (as you might think) because I am unable to make a clear statement on this matter; it is because I will not hold your attention enough to my work, if I expound it to you abruptly.(treatise)

(8) [x] malgré la parole que je lui avais donnée que je ne la reverrais jamais, elle a, ce matin, jugé à propos de m'écrire, $\left[\mathrm{z}_{[\mathrm{y}]}\right]$ moins encore, comme vous pourriez le croire, pour tenter un raccommodement, que pour feindre de la jalousie, et pour m'accabler, au surplus, de toutes les injures imaginables. (Crébillon Fils, Lettres athéniennes extraites du porte-feuille d'Alcibiade, 1771)

$[\mathrm{x}]$ in spite of my word that I had given to her that I would never see her again, she deemed it appropriate this morning to write to me, $\left[\mathrm{z}_{[\mathrm{y}]}\right]$ still less, as you might believe, to try and make amends, than to feign jealousy and to overwhelm me, incidentally, with the grossest insults. (novel)

The fact that $[\mathrm{z}]$ "responds" to $[\mathrm{y}]$ is marked by the syntactic parallelism of both elements of the correlation: subordinates of purpose in (6) and (8); subordinates of cause in (7). The speaker corrects in advance the interpretation $[\mathrm{y}]$ that the reader could make of his/her previous utterance $[\mathrm{x}]$, by integrating it to the syntax of the element $[\mathrm{z}]$ in the form of the first element of the negative correlation with rectification (non pas $[\mathrm{y}]$...mais au contraire / 'not [y] ... but on the contrary' (...)) (6), of the contrastive pseudo-cleft sentence (si P, ce n'est pas parce que [y], c'est parce que (...) / 'if $\mathrm{P}$, it is not because [y], it is because' (...)) (7), of the comparison (moins [y] que (...) / 'less [y] than' (...)) (8). If the element $[y]$ is the most often inserted as the first element of the correlation, it is because this location enables us to outline its role of "response" to the previous element [x]. This role of a response ascribed to the recipient is most often implicit, but it becomes clearer, in the occurrences (6-8), by the subordinates «comme vous pourriez le croire » ('as you might believe it'), or « comme vous pourriez le penser » ('as you might think it'): the pronoun le ('it'), as a cataphora of the elements [y], is a complement of the verbs croire ('believe') and penser ('think'), whose subject is the recipient represented by the pronoun vous ('you').

\subsubsection{Integration by subordination}

The anticipated response [y] can be integrated in the utterance $[\mathrm{z}]$ other than by correlation: by subordination, as in (9):

(9) (Présentation du film Stardust, le mystère de l'étoile)

(...) $[\mathrm{x}]$ Un univers onirique qui ravira les amateurs de merveilleux. [ $\left.\mathrm{z}_{[\mathrm{y}]}\right]$ Bien sûr que c'est naïf et alors??? Très dense dans sa narration, le film est habité de la mélancolie des vieux livres d'images. (La Gazette, 8-14 nov. 2007)

(Presentation of the film Stardust)

(...) $[\mathrm{x}]$ An oneiric universe which will ravish those who love fantasy. $\left[\mathrm{z}_{[\mathrm{y}]}\right]$ Of course it may seem simplistic, so what??? Quite dense in its storytelling, the film oozes with melancholia from old picture books. (weekly cultural magazine)

The element [y] «c'est naïf» ('it may seem simplistic'), a reaction ascribed to the reader when reading [x], is subordinated by que to the adjectival group bien sûr ('of course'): the writer thus admits the negative evaluation he/she imagines his/her reader might have that would oppose his/her 
own positive evaluation [x] of the film Stardust. Let us note in this case also that it would be possible to add an incise which explains that [y] is ascribed to the recipient: «bien sûr que, comme vous pouvez le penser, c'est naïf » ('of course, as you could think it, it is simplistic').

\subsection{Integration by a process of amalgamation}

The element [y] can be even more strongly integrated into the syntax of $[\mathrm{z}]$ : this time not by correlation or subordination but by what we call amalgamation, as in the predicative negation:

(10) Alexandre Bain est jugé comme «iconoclaste» par ceux qu'il faut bien nommer ses «confrères » de l'appellation Pouilly-Fumé. Ceux-ci lui reprochent des tas de trucs et oublient que le trublion participe aussi de [x] la renommée mondiale, $\left[\mathrm{z}_{[\mathrm{y}]}\right]$ je n'exagère pas, de leur appellation. Moi je juge le vin, les différentes propositions d'Alexandre. (L'Opinion, 13 février 2015)

Alexandre Bain is deemed to be an «iconoclast» by those who must be called his/her «colleagues» of the Pouilly-Fumé designation. The latter reproach him for many things and forget that the troublemaker also contributes to $[\mathrm{x}]$ the world reputation of their label, $\left[\mathrm{z}_{[\mathrm{y}]}\right]$ and I don't exaggerate ${ }^{7}$. I for one judge the wine, the different propositions of Alexandre. (daily newspaper)

The refutation by the negative provided by the writer in his/her utterance $[\mathrm{z}]$ «je n'exagère pas » ('and I don't exaggerate') incorporates the implicit response ascribed to the reader: [vous exagérez] ('you exaggerate'), in what could be called a discursive amalgamation. In addition to the negative (10), this type of integration by amalgamation can be achieved through interrogation (supra (1) and (11)), concession (12), cleft sentence (13), repeat-echo (14).

(11) (courriel entre membres du Conseil d'administration d'université. L'objet est de savoir s'il convient de faire un recours contre l'utilisation abusive de procurations) [x] Après une nuit qui est censée avoir porté conseil, je me réveille partisan du recours. $\left[\mathrm{z}_{[\mathrm{y}]}\right]$ Les recours sont mal vus dans la communauté universitaire ? Eh bien expliquons-nous (...). (courriel, avril 2009)

(email between members of the University Management Board. The object is to find out whether there are grounds to lodge an appeal against the overuse of proxies) [x] Having supposedly slept on it, when I wake I am in favour of the appeal. $\left[\mathrm{z}_{[\mathrm{y}]}\right]$ Appeals are looked down on in the university community? So, let's explain ourselves. (email)

The interrogative utterance «Les recours sont mal vus dans la communauté universitaire?» ('Appeals are looked down on in the university community?') amalgamates the affirmative responsive speech [y] ascribed to the reader: [Les recours sont mal vus dans la communauté universitaire] ('Appeals are looked down on in the university community'), together with the writer's question $[\mathrm{z}]$.

(12) $[\mathrm{x}]$ j'ai beau me regarder, je ne peux me trouver déchue jusque-là. $\left[\mathrm{z}_{[\mathrm{y}]}\right]$ C'est peut-être un tort que j'ai; mais je vous préviens que j'en ai beaucoup d'autres encore. (Laclos, Les liaisons dangereuses, 1782)

[x] however much I look in the mirror, I cannot say I have lost my bloom so far. $\left[\mathrm{z}_{[\mathrm{y}]}\right]$ I may be completely wrong; but I warn you that I have many other shortcomings still. (novel)

The concessive utterance «C'est peut-être un tort que j'ai» ('I may be completely wrong') amalgamates the affirmative responsive speech [y] ascribed to the addressee of the letter: [c'est un tort] ('you are completely wrong'), together with its concession by the writer (peut-être ('maybe'), element of $[\mathrm{z}])$.

\footnotetext{
${ }^{7}$ For greater legibility, the assembly $\left[\mathrm{z}_{[\mathrm{y}]}\right]$ is put in bold in section 3.2 .
} 
(13) Les vignerons de l'AOC Saint-Chinian (au nord-ouest de Béziers) fêtent aussi la Saint-Vincent. L'appellation Saint-Chinian, regroupe depuis vingt ans, une vingtaine de villages situées au nord-ouest de Béziers. [x] Chaque année, le saint patron est fêté dans un village différent. $\left[\mathrm{z}_{[\mathrm{y}]}\right]$ C'est à Cruzy, en bordure du canal du Midi, que se tiendront les agapes 2003. (La Gazette, 24/30-01-2003).

The wine-growers of the AOC Saint-Chinian designation (to the Northwest of Béziers) also celebrate SaintVincent's Day. The Saint-Chinian designation has brought together, over twenty years, some twenty villages

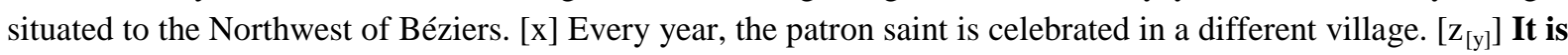
in Cruzy, on the banks of the Canal du Midi, that the 2003 Festival will be held. (weekly cultural magazine)

The cleft sentence "C'est à Cruzy, en bordure du canal du Midi, que se tiendront les agapes 2003 » ('It is in Cruzy, on the banks of the Canal du Midi, that the 2003 Festival will be held') amalgamates the interrogative [y] ascribed to the reader: [où se tiendront les agapes 2003?] ('where will the 2003 Feast be held?'), together with the answer provided thereto by the writer using the focused element of [z] («à Cruzy, en bordure du canal du Midi » ('in Cruzy, on the banks of the Canal du Midi').

(14) Ils seront 100000 paysans à faire le déplacement vers Cancun, avec pour slogan « El campo no aguanta mas ». Ce qu'ils revendiquent? La renégociation de l'accord de libre-échange de l'Amérique du Nord. (Le Monde, 7 septembre 2003).

100,000 farmers will make the trip to Cancun, with the slogan «El campo no aguanta mas ${ }^{8}$. What is it they claim? The renegotiation of the free trade agreement with North America. (daily newspaper)

The interrogative utterance «Ce qu'ils revendiquent? ('What is it they claim?') amalgamates the interrogative [y] ascribed to the reader: [qu'est-ce qu'il revendiquent?] ('what do they claim?'), together with the repeat-echo by the writer «Ce qu'ils revendiquent? ('What is it they claim?'). This echo is expressed in the syntactic pattern of French indirect interrogative: (vous me demandez) ce que P? ('are you asking me what $\mathrm{P}$ ?').

Let us now turn our attention to the case of the left dislocation of an adjective with the relative superlative (15), which also seems to amalgamate [y] with the topical portion of [z]:

(15) [x] En fait, ce jour-là, Bernard Tapie se livre à un exercice de comédien dont il a le secret. Des sanglots dans la voix, il prétend que le Crédit Lyonnais l'a non seulement floué lors de la revente d'Adidas, mais l'a de surcroît, à la même époque, traîné dans la boue. C'est donc à ce titre qu'il revendique une indemnité au titre du préjudice moral.

$\left[\mathrm{z}_{[y]}\right]$ Et le plus stupéfiant, c'est que cela marche. (Mauduit L., Tapie le scandale d'Etat,)

[x] In fact, that day, Bernard Tapie comes across as a drama king in his/her inimitable style. Tearfully, he claims that the Crédit Lyonnais short changed him not only when they resold Adidas, but additionally, at the same time, when they dragged him through the mud. It is therefore on these grounds that he seeks compensation for moral prejudice.

$\left[\mathrm{z}_{[y]}\right]$ And most stupefying, it works. (biography)

Left dislocation can be described (XXXX 2012) as a dialogic repetition of a previous syntagm. When the detached element is an adjective with a relative superlative (le plus drôle, le moins évident / 'most amazing, least obvious' etc.), dislocation is analyzed as a comparative turn with the potential evaluative speech of the reader. In (15), the writer ascribes to his/her reader, when reading paragraph [x], a reaction $[\mathrm{y}]$ - such as [c'est stupéfiant] ('it is stupefying'), an evaluation with which he interacts by the superlative: «le plus stupéfiant, c'est (...)» ('most stupefying, it...'). Interaction with this potential responsive speech of the reader is highlighted in (15) by placing the text in paragraphs: dislocation opens a new paragraph as an increase in the reaction ascribed to the reader when reading the previous paragraph.

\footnotetext{
${ }^{8}$ Translation: The fields can't take it anymore.
} 
As we have seen previously, prolepsis takes on certain forms of reported speech, and distinguishes the speech ascribed to the recipient [y] and the answer to this speech [z]. In a different way, integration eliminates any trace of reported speech and moulds the elements $[\mathrm{y}]$ and $[\mathrm{z}]$ of the sequential pattern into a single utterance $\left[\mathrm{z}_{[\mathrm{y}]}\right]$.

\section{Ellipsis: $[x] \rightarrow[y] \rightarrow[z]$}

Ellipsis refers to the omission of one or more words in an utterance that are nevertheless understood in the context of the remaining elements.

In this third form of anticipative interlocutive dialogism, the utterance [y] ascribed to the recipient is neither reported nor integrated into the response [z] given by the speaker, but it is presupposed by this utterance $[\mathrm{z}]$ which can only be understood as a response to this non-fulfilled utterance $[\mathrm{y}]$. So, let us represent the ellipsis of $[\mathrm{y}]$ by a strike through: $[\mathrm{x}] \rightarrow[\mathrm{y}] \rightarrow[\mathrm{z}]^{9}$. We shall distinguish the cases where $[\mathrm{z}]$ confirms or refutes an implicit utterance $[\mathrm{y}]$ from the cases where $[\mathrm{z}]$ responds in advance to a possible difficulty of understanding, to a question or a request for clarification from the recipient.

\subsection{Confirmation, refutation}

The adverb parfaitement ('perfectly') (16), which can be preceded by the adverb oui ('yes') (17), signals that $[\mathrm{z}]$ answers an implicit questioning ascribed to the recipient:

(16) J'ai lu tout Hegel, je le jure (...) et Lénine... [x] Les trente-six volumes de Lénine, [z] parfaitement ! Ah mais ! Et Freud... (Sollers Ph., Femmes, 1983)

I have read all Hegel's works, I swear (...) and Lenin... [x] The thirty-six volumes of Lenin, [z] perfectly! Yes indeed! And Freud... (novel)

(17) $[\mathrm{x}]$ le progrès dans la productivité, comment l'obtenir, sinon par la coopération active du personnel tout entier? [z] Oui, parfaitement ! il faut que tout le monde s'y mette et que chacun y ait intérêt. (de Gaulle Ch., Discours et messages, , 1946-1958)

[x] an increase in productivity, how can it be obtained, if not through active cooperation of the whole staff? [z] Yes, perfectly! Everyone should play a part and find an interest therein. (political discourse)

The utterances [z] «Parfaitement!» ('Perfectly!') and «Oui, parfaitement (...)» ('Yes, perfectly!') can be understood only as answering to the possible reaction of incredulity [y] which has not been reported, but presupposed, ascribed to the reader, a reaction echoing the utterance [x] of the writer. So, the utterance [y] can be reconstructed:

$[\mathrm{x}]$ Les trente-six volumes de Lénine $\rightarrow[\mathrm{y}]$ Hes trente-six volumes de Lénine,?] $\rightarrow[\mathrm{z}]$ parfaitement !

$[\mathrm{x}]$ The thirty-six volumes of Lenin $\rightarrow[\mathrm{y}][$ The thirty-six volumes of Lenin,?] $\rightarrow[\mathrm{z}]$ perfectly!

[x]le progrès dans la productivité, comment l'obtenir, sinon par la coopération active du personnel tout entier ?

$\rightarrow$ [y] [par la coopération active du personnel tout entier ?] $\rightarrow[\mathrm{z}]$ Oui, parfaitement ! il faut que (...)

$[\mathrm{x}]$ an increase in productivity, how can it be obtained, if not through active cooperation of the whole staff? $\rightarrow$ [y] [through active cooperation of the whole staff?] $\rightarrow[\mathrm{z}]$ Yes, perfectly! Everyone should (...)

Similarly, the refutation adverbs of an affirmative utterance (non / 'no') in (18) or negative (si / 'absolutely') in (19) may reflect the speaker refuting an utterance he/she ascribes to the recipient:

\footnotetext{
${ }^{9}$ In the following occurrences, the element $[\mathrm{z}]$ is put in bold
} 
(18) $[\mathrm{x}]$ tu m'as jamais aimée... [z] non non... inutile de venir maintenant me raconter des salades ! (courriel avril 2009 )

$[\mathrm{x}]$ you have never loved me... [z] no no... there is no point in making up stories now! (email)

(19) [x] J'écris comme viennent les phrases, au plus près de ce que j'ai à exprimer... [z] Mais si ! Vous n'imaginez pas que je pourrais écrire Le Temps immobile, six gros volumes déjà, si je m'arrêtais sur chaque phrase... (Mauriac Cl., Mauriac et fils, 1986)

[x] I write sentences as I go along, trying to express myself as precisely as I can... [z] Absolutely! You cannot imagine that I could write (Time stands still), six large volumes already, if I stopped at each sentence... (diary)

The adverbs non ('no') et si ('absolutely') are used conventionally to contradict a previous utterance of the speaker. In the analyzed occurrences, they presuppose a previous utterance, affirmative in (18), negative in (19). By using these adverbs in a monologal text, the speaker anticipates the utterances he/she presupposes and assigns them to the recipient, so as to refute them by [z].

$[\mathrm{x}]$ tu m'as jamais aimée $\rightarrow[\mathrm{y}]$ [sije t'ai aimé $] \rightarrow[\mathrm{z}]$ non non... inutile de venir maintenant me raconter des salades !

you have never loved me $\rightarrow[\mathrm{y}]$ [indeed I did love you $\rightarrow[\mathrm{z}]$ no no... there is no point in making up stories now!

$[\mathrm{x}] \mathrm{J}$ 'écris comme viennent les phrases $\rightarrow$ [y] [e'est pas vrai] $\rightarrow[\mathrm{z}]$ Mais si! Vous n'imaginez pas que $(\ldots)$

$[\mathrm{x}]$ I write sentences as I go along $\rightarrow[\mathrm{y}]$ [it is not true $\rightarrow[\mathrm{z}]$ Absolutely! You cannot imagine that $(\ldots)$

\subsection{Clarification}

The speaker anticipates a possible difficulty of understanding from the addressee and replies in advance of the request for clarification that he/she might put in. He/she can do so by using a right dislocation (XXX 2009), a vocative or glosses (i. a. Authier-Revuz 1994, 1995; Steuckardt and Niklas-Salminen 2003).

\subsubsection{Right dislocation}

Topicalization through right dislocation can be analyzed as a reply to a request for clarification ascribed to the addressee:

(20) (Commentaire télévisuel en direct de l'ascension mano a mano du Tourmalet par les deux coureurs A.

Schleck et A. Contador, lors du Tour de France, 22 juillet 2010):

Schleck a lancé un regard à Contador pour lui dire qu' $[\mathrm{x}]$ il arrivera pas [z] Contador à le lâcher

(Live televisual comment of the bicycle ascension of the Tourmalet climb by the two cyclists A. Schleck and A. Contador, during the Tour de France, 07. 22. 2010): Schleck casting a glance at Contador is telling him that $[\mathrm{x}]$ he will not $[\mathrm{z}]$ Contador shake him off (TV live coverage)

The pronoun il ('he'), subject of the predicate «arrivera pas » ('will not shake him off'), carries a referential ambiguity: two antecedents are competing for a single pronoun which may anaphorise Schleck as well as Contador. The clarification of the pronoun il ('he') by the dislocated noun Contador resolves the potential referential ambiguity: il ('he') anaphorises Contador. We shall analyze this right dislocation as a reply from the sports commentator to the question the viewers may ask (themselves): 
pour lui dire qu' $[\mathrm{x}]$ il arrivera pas $\rightarrow[\mathrm{y}]$ [qui il ?] $\rightarrow$ [z] Contador à le lâcher

to tell him that $[\mathrm{x}]$ he will not $\rightarrow[\mathrm{y}]$ [who is $h e ?] \rightarrow[\mathrm{z}]$ Contador shake him off

\subsubsection{Vocative}

In double recipiency situations, in particular in a media interview, "the participation framework is characterized not only by the interaction between the speaker and his/her addressee but also by the orientation and often the reference to an overhearing audience" (Mondada 2015). In this type of interaction, the repeated vocative of the interviewee's first name and surname can be observed frequently. Let us consider the following occurrence, noted on the radio channel France Culture, on 17.03.2015, during the cellist, Ophélie Gaillard's, interview:

(21) [x] Comment avez-vous découvert Le Château intérieur de Thérèse d'Avila, [z] Ophélie Gaillard ?

[x] How did you discover Le Château intérieur (the inner castle of) Thérèse d'Avila, [z] Ophélie Gaillard? (radio interview)

The vocative "Ophélie Gaillard», was repeated throughout the interview, almost every time the interviewer addressed his guest. However, this use of the vocative is only relevant for the listeners who, if they join in after the interview has started, may wonder about the identity of the person interviewed. By calling out the first name and surname of his guest, the interviewer replies in advance to the potential question he/she imagines that the listeners may ask themselves.

That is to say:

[x] Comment avez-vous découvert $(\ldots) \rightarrow[\mathrm{y}]$ (à qui l'intervieweur s'adresse-t-il ?) $\rightarrow$ [z] Ophélie Gaillard

$[\mathrm{x}]$ How did you discover $(\ldots) \rightarrow[\mathrm{y}]($ whom is the interviewer talking to?) $\rightarrow[\mathrm{z}]$ Ophélie Gaillard

\subsubsection{Glosses}

A gloss can be seen as a linguistic operation focusing on a word or a syntagm to clarify its meaning: it constitutes an explanation illocutionary act. It may be expressed by verbal markers (à savoir, en clair, en d'autres termes, c'est-à-dire, etc. /'that is to say', 'to be clear', 'in other words', 'i.e.', etc.) and / or, in written text, by graphic markers (quotes, typographical dash, footnote).

- There are so many verbal markers of gloss that it would be a never ending list. We will merely point out two of them here: autrement dit ('in other words') and c'est-à-dire ('i.e.'):

(22) les partisans d'une réforme plus radicale (de la loi sur la fin de vie) proposent que soit ouvert un droit à bénéficier d'une $[\mathrm{x}]$ «assistance médicalisée active à mourir », $[\mathrm{z}]$ autrement dit un droit au suicide assisté. (Le Monde, 10 mars 2015)

the partisans of a more radical reform (of the law concerning the end-of-life) propose the opening of a right to benefit from an $[\mathrm{x}]$ "an active medical assistance to die", $[\mathrm{z}]$ in other words a right to assisted suicide. (daily newspaper)

(23) Que nous dit le changement climatique? Que notre système [x] extractiviste, [z] c'est-à-dire basé sur l'extraction intensive de nos ressources naturelles, qui repose sur une croissance illimitée, a échoué. (Télérama, 14 mars 2015)

What is climate change telling us? That our extractivistic [x] system, $[z]$ i. e. based on the intensive extraction of our natural resources, which rests on unlimited growth, has failed. (weekly cultural magazine) 
Autrement dit ('In other words') as well as c'est-à-dire ('i. e.') demonstrate, from a semantic viewpoint, an equivalence of meaning between «assistance médicalisée active à mourir 》 ('active medical assistance to die') and «droit au suicide assisté » ('right to assisted suicide') in (22); and between «extractiviste» ('extractivistic') and «basé sur l'extraction intensive de nos resources naturelles » ('based on the intensive extraction of our natural resources') in (23). According to the dialogic perspective, one may add that, through these gloss markers, the writer takes the reader's understanding on board: after a term that he/she deems opaque, he/she provides clarification beforehand in order to reply in advance to questions the recipient might formulate:

$[\mathrm{x}]$ assistance médicalisée active à mourir $\rightarrow[\mathrm{y}]$ [qu'est-ce que cela veut dire $? \rightarrow[\mathrm{z}]$ autrement dit droit au suicide assisté

$[\mathrm{x}]$ active medical assistance to die $\rightarrow[\mathrm{y}]$ [what does it mean ? $\rightarrow[\mathrm{z}]$ in other words a right to assisted suicide

$[\mathrm{x}]$ extractiviste $\rightarrow[\mathrm{y}]$ [qu'est-ce que cela veut dire ?] $\rightarrow[\mathrm{z}]$ c'est-à-dire basé sur l'extraction intensive de nos ressources naturelles

$[\mathrm{x}]$ extractivistic $\rightarrow[\mathrm{y}]$ [what does it mean?] $\rightarrow[\mathrm{z}]$ i. e. based on the intensive extraction of our natural resources

- Graphic markers: brackets (24), typographical dash (25) (or still footnote) can operate as gloss markers:

(24) Faut-il armer la Chine ? [...] Les Européens ont mis en place un embargo sur les exportations d'armes [x] létales $[z]$ (mortelles) vers la Chine [...]. Ce dispositif n'interdit nullement de vendre des armes non létales, d'autant que les règles s'appliquant aux matériels à caractère $[\mathrm{x}]$ dual [z] (dont l'emploi peut être à la fois civil et militaire) ouvrent la voie à des interprétations laxistes. (Le Monde, 12 avril 2005)

Should China be armed? [...] The Europeans have implemented an embargo on [x] lethal [z] (mortal) arms exports to China [...]. This regulation does not prohibit in the least the sale of non-lethal arms, all the more so since the rules apply to equipment with a $[\mathrm{x}]$ dual character $[\mathrm{z}]$ (whose usage can be both civilian and military), opening the path to laxest interpretations. (daily newspaper)

According to a conventional description, the brackets enable the writer to introduce a clarification of the meaning of the technical terms immediately preceding them, i.e. the adjectives letales ('lethal') for the first occurrence and dual ('dual') for the second. In the dialogic perspective, one may add that the writer replies in advance to the request for clarification which the reader might voice when reading those terms. That is to say he/she clarifies this presupposed element $[\mathrm{y}]$ :

les exportations d'armes $[\mathrm{x}]$ létales $\rightarrow[\mathrm{y}]$ fqu'est-ce que cela veut dire $?] \rightarrow[\mathrm{z}]$ (mortelles) vers la Chine $(\ldots)$

the $[\mathrm{x}]$ lethal $\rightarrow[\mathrm{y}]$ [what does it mean?] $\rightarrow[\mathrm{z}]$ (mortal) arms exports towards China $(\ldots)$

We shall give the same type of description for the typographical dash:

(25) Face au désespoir et au cynisme généralisés, retrouvons l'esprit de fraternité

(...) Nous sommes déçus de devoir supporter sur nos écrans ces visages déformés par la haine et le rejet de l'autre. Nous comptons [x] sur les doigts de la main de Django Reinhardt - $[\mathrm{z}]$ le guitariste manouche avait perdu deux doigts dans l'incendie de sa roulotte - quelques hommes d'honneur qui ont su prendre date avec la nation. (Le Monde, 5 janvier 2011)

Confronted with general despair and cynicism, let us revive the spirit of fraternity

(...) We are disappointed when we have to put up with these faces deformed by hatred and the rejection of others on our screens. We can count $[\mathrm{x}]$ on the fingers of the hand of Django Reinhardt $-[\mathrm{z}]$ the gipsy guitar player had lost two fingers in the fire of his caravan - a few men of honour who knew when to make an appointment with the nation. (daily newspaper) 
The idiomatic expression compter sur les doigts d'une main ('count on the fingers of one hand') refers to a small number. The writer renews this old metaphor by adding the possessive phrase «de Django Reinhardt» ('the fingers of Django Reinhardt'). But his/her reader might have trouble understanding this, unless he/she is a jazz lover: the writer anticipates this potential difficulty and replies in advance to the reader by framing a parenthetical clause within a pair of dashes: «-le guitariste manouche avait perdu deux doigts dans l'incendie de sa roulotte - ('the gipsy guitar player had lost two fingers in the fire of his caravan'). This gloss clarifies the relevance of the expression.

\footnotetext{
Nous comptons $[\mathrm{x}]$ sur les doigts de la main de Django Reinhardt $\rightarrow[\mathrm{y}]$ [qu'est-ce que cela veut dire $?] \rightarrow[\mathrm{z}] \mathrm{le}$ guitariste manouche avait perdu deux doigts dans l'incendie de sa roulotte (...)
}

We can count $[x]$ on the fingers of the hand of Django Reinhardt $\rightarrow[y]$ [what does it mean?] $\rightarrow[z]$ the gipsy guitar player had lost two fingers in the fire of his caravan (...)

Let us note that the verbal marker of the gloss can combine with the typographic marker, as in (26) where the verbal gloss en clair ('to be clear') is introduced by a dash:

(26) Le texte de l'IPCC présente une autre affirmation : [x] l'Asie du Nord [z] - en clair, la Chine - devrait subir un réchauffement plus accentué encore que la moyenne. (Le Monde, 3 novembre 2000)

The text of the IPCC presents another assertion: $[\mathrm{x}]$ Northern Asia $[\mathrm{z}]$ - to be clear, China - will experience stronger warming than average. (daily newspaper)

That is to say by clarifying the presupposed element $[y]$ :

$$
\begin{aligned}
& {[\mathrm{x}] \text { l'Asie du Nord } \rightarrow[\mathrm{y}](\text { c'est-à-dire } ?)^{\prime} \rightarrow[\mathrm{z}]-\text { en clair, la Chine }-(\ldots)} \\
& {[\mathrm{x}] \text { Northern Asia } \rightarrow[\mathrm{y}] \text { (which means?) } \rightarrow[\mathrm{z}]-\text { to be clear, China }-(\ldots)}
\end{aligned}
$$

In the occurrences (16-26), confirmation or refutation adverbs (16-19), topicalization by right dislocation (20), vocative (21), verbal (22-23) and graphic (24-26) glosses that can be found in [z] are evidence that this utterance replies to an implicit utterance [y] ascribed to the recipient in relation to $[\mathrm{x}]$.

Overview: the speaker, as he/she is progressing in his/her speech (element $[\mathrm{x}]$ ), imagines the reactions of his/her addressee (element [y]), i.e. the objections he/she might raise, the questions he/she might ask, the clarifications he/she might request; and he/she answers them in advance (element $[\mathrm{z}]$ ) by reporting them (prolepsis), by integrating them syntactically (integration) or by presupposing them (ellipsis).

\section{Synthesis and discussion of main results}

In this paper we have tried to tackle the question of anticipative interlocutive dialogism, a so far little explored dimension of verbal communication. It has led us to describe three discourse structures - prolepsis, integration and ellipsis - through which the speaker interacts in advance, as he/she is progressing through his/her speech, with the responsive speech he/she attributes to the addressee and which he/she constantly anticipates.

The characteristics shared by these three discourse structures can be framed into a sequential pattern, which is composed of three successive elements: [x] speaker's utterance; [y] utterance ascribed to the addressee by the speaker, in reply to $[\mathrm{x}] ;[\mathrm{z}]$ speaker's utterance, in reply to $[\mathrm{y}]$. We 
have shown that these three elements are organized in three structures, according to the way the element $[y]$ ascribed to the addressee is processed by the speaker:

$$
\begin{array}{ll}
\text { - prolepsis: } & {[\mathrm{x}] \rightarrow \mathrm{RS}[\mathrm{y}] \rightarrow[\mathrm{z}]} \\
\text { - integration: }[\mathrm{x}] \rightarrow\left[\mathrm{z}_{[\mathrm{y}]}\right] & \\
\text { - ellipsis: } & {[\mathrm{x}] \rightarrow[\mathrm{y}] \rightarrow[\mathrm{z}]}
\end{array}
$$

As a direct result, the syntactic elements that help shape these structures can be classified and explained as follows:

- prolepsis relies on the use of reported speech;

- integration hinges on several kinds of syntactic correlation or amalgamation:

- correlation, which is always based on a form of syntactic parallelism, can be operated by addition, a rectifying negative, a pseudo-cleft sentence, or a comparative construction;

- syntactic amalgamation can be operated through a predicative negation, an interrogative utterance, a concessive construction, a repeat-echo, a cleft-sentence, or by the left dislocation of the superlative adjective;

- ellipsis can be based on the use of adverbs of confirmation or contradiction; it can also be expressed by a right dislocation, a repetition of the vocative, or it can be conveyed by making a gloss.

As an additional result, the sequential pattern based on three chained elements $([\mathrm{x}] \rightarrow[\mathrm{y}] \rightarrow[\mathrm{z}])$ appears to be somewhat reminiscent of the structure of a ternary exchange in a conversation between two co-participants: $\left[\mathrm{A}_{1}\right] \rightarrow\left[\mathrm{B}_{2}\right] \rightarrow\left[\mathrm{A}_{3}\right]$. Indeed the internal dialogue of dialogism seems to be quite similar to the external dialogue of verbal interactions. This can be inferred from the fact that the element $[\mathrm{z}]$ in anticipative interlocutive dialogism is sometimes expressed by the same discourse markers as $\left[\mathrm{A}_{3}\right]$ in verbal interaction: for instance the enunciative adverbs parfaitement ('perfectly'), non ('no'), mais si ('absolutely'), which belong to the conversational repertoire of any native speaker.

\section{Conclusion}

We have described anticipative interlocutive dialogism as a discursive interaction between the speaker and the response he/she continuously anticipates from his/her addressee: while proceeding through his/her speech, the speaker responds in advance to this anticipated response.

Most of the syntactic forms displayed by this type of dialogism are common to the two other types (interdiscursive and intralocutive dialogism). Let us illustrate this by using an example of predicative negation. The negative can be involved in anticipative interlocutive dialogism (cf. supra 3.2., (10) : «je n'exagère pas », "I don't exaggerate"). But it can also take part in interdiscursive dialogism as well (cf. 27):

(27) Ukraine: Les opposants ne sont pas des extrémistes (Le Monde, 8. 1. 2014, titre d'article)

Ukraine: The opponents are not extremists (headline, daily newspaper)

The newspaper article goes on to say that this negative headline refutes a previous utterance attributed to the "intelligence services of the Kremlin", according to which "the (Ukrainian) 
opponents are terrible pro fascist nationalists". Here, the predicative negative in the headline is a tool for interdiscursive dialogism.

Furthermore, since the same means of expression can become, in different utterances, a linguistic tool for different types of dialogism, it follows that a single utterance can sometimes be analyzed in terms of different types of dialogism, for instance both interdiscursive and interlocutive. In other words, a single utterance can sometimes be analyzed both in terms of interdiscursive dialogism and interlocutive dialogism, i.e. in the same utterance, the speaker may dialogically echo a third party's speech as well as his recipient's speech. Let us consider for instance the following interrogation occurrence, which contains both types of dialogism:

(28) Ségolène Royal est désormais la seule à pouvoir remettre le rose aux joues des électeurs. Elle est détestée? Les autres aussi. Elle est ambitieuse? Qui ne l'est pas? Elle est bourgeoise? Les autres aussi! (Le Monde, journal, 14. 4. 2006)

Ségolène Royal ${ }^{10}$ is from now on the only one who can put some colour in electors' cheeks. She is loathed? So are the others. She is ambitious? Who is not? She is a bourgeoise? So are the others! (newspaper)

Each of these questions implies debating over one of the following utterances: [elle est détestée] ('she is loathed'), [elle est ambitieuse] ('she is ambitious'), [c'est une bourgeoise] ('she is a bourgeoise'). Each of these implicit utterances can be understood, firstly as a repeat of something previously said by a third party, other than both the writer and the reader (interdiscursive dialogism). This interpretation is backed up by the fact that the writer could add "so they say" to his/her own utterance.

But according to a second interpretation, these implicit utterances can also be understood as objections that the writer anticipates from his/her reader (interlocutive dialogism): a series of objections to his/her previous statement, i.e. Ségolène Royal is the only one (among Socialists) who can run for the presidential election. That second interpretation is backed up by the likeliness of adding: "you will say", as in: "She is loathed, you will say?"

Nevertheless, while most of the linguistic means of expression are common to different types of dialogism, the gloss seems specific to anticipative interlocutive dialogism. This is due to the fact that through a gloss, the speaker performs an explanation act in response to the implicit request for clarification, i.e. [y], ascribed to the recipient to whom the speaker gives an answer, i.e. element [z]. This request-answer dynamic of discourse can only be viewed in the light of an interlocutory relationship: the relationship which binds the speaker, i.e. the writer, with his/her recipient, i.e. the reader.

However, let us note here that making a gloss not only involves interlocutive, but also intralocutive dialogism as well: in order to reply in advance to questions ascribed to the recipient, the speaker reformulates a word from his/her own speech. That kind of "start over" means that the speaker interacts with his/her own utterance, in the midst of his/her self-receiving process (intralocutive dialogism).

This research has been conducted on the French language: we put forward the hypothesis that anticipative interlocutive dialogism is a dimension of communication which, as such, occurs in all languages, certainly with specificities related to the particular syntactic structure of each. We plan to examine this hypothesis in later research work.

\footnotetext{
${ }^{10}$ The socialist candidate at the presidential election of 2007.
} 
We also intend to expand our research on the basis of the following questions: is anticipative interlocutive dialogism marked identically or differently when speaking or when writing? In monologal or in dialogal texts? Are there generic specificities? And finally, beyond the verbal mode, does anticipative interlocutive dialogism appear in the mimico-gestual mode?

\section{Bibliographic references}

Authier-Revuz, Jacqueline, 1994. L'énonciateur glosateur de ses mots : explicitation et interprétation, Langue française 103, 91-102.

Authier-Revuz, Jacqueline, 1995. Ces mots qui ne vont pas de soi, Paris : Larousse.

Bakhtine, Mikhaïl, 1978 [1934/1975]. Du discours romanesque, in Esthétique et théorie du roman, Paris : Gallimard, Tel, 83-233.

Bakhtin M. M., 1986 [1952/1979]. The Problem of Speech Genres. In Speech Genres and other late Essays, Austin: University of Texas Press, 60-102.

Bakhtine, Mikhaill, 1970 [1963]. Problèmes de la poétique de Dostoïevski, Lausanne : L'âge d'homme.

Bronckart, Jean Paul et Bota, Christian, 2011, Bakhtine démasqué. Histoire d'un menteur, d'une escroquerie et d'un délire collectif, Genève : Librairie Droz.

Deppermann, Arnulf, 2014. "Don't get me wrong": Recipient design by using negation to constrain an action's interpretation, In Susanne Günther, Wolfgang Imo, Jörg Bücker (eds.), Grammar and Dialogism: Sequential, Syntactic, and Prosodic Patterns between Emergence and Sedimentation, Berlin: De Gruyter Mouton, 15-52.

Du Bois, John W., 2014. Towards a dialogic syntax, Cognitive Linguistics 25(3): 359-410.

Goodwin, Charles, 2007. Interactive footing. In: Holt, Elizabeth \& Clift, Rebecca (Eds.), Reporting Talk: Reported Speech in Interaction, 16-46. Cambridge: Cambridge University Press.

Günthner, Susanne, 1999. Polyphony and the "layering of voices". In: Reported dialogues: An analysis of the use of prosodic devices in everyday reported speech. Journal of Pragmatics 31(5), 685-708.

Günthner, Susanne, Imo, Wolfgang \& Bücker, Jörg (Eds.), 2015. Grammar and dialogism. Berlin: Mouton.

Lambrecht, Knud, 1994. Information structure and sentence form: Topic, focus, and the mental representations of discourse referents. Cambridge: Cambridge University Press.

Mondada, Lorenza, 2015 (To be published). The facilitator's task of formulating citizens' proposals in political meetings: Orchestrating multiple embodied orientations to recipients, Gesprächsforschung. (http://www.gespraechsforschung-ozs.de)

Ochs Elinor, Schegloff Emanuel A. \& Thompson Sandra A. (ed.), 1996, Interaction and grammar, Cambridge University Press.

Steuckardt, Agnès \& Niklas-Salminen, Aïno, 2003, Le mot et sa glose, Université de Provence: Publications de l'Université de Provence.

Sacks, Harvey, Schegloff, Emanuel A., and Jefferson, Gail, 1974. A simplest systematics for the organization of turntaking for conversation. Language, 50, 696-735.

Schegloff, Emanuel A., Turn organization: one intersection of grammar and interaction. In Elinor Ochs, Emanuel

Schegloff and Sandra A. Thompson (Eds.), Interaction and Grammar. Cambridge: Cambridge University Press, 52-133.

Schwenter, Scott A. 2000. Viewpoints and polysemy: Linking adversative and causal meanings of discourse markers. In

Elizabeth Couper-Kuhlen and Bernd Kortmann, eds., Cause -Condition - Concession - Contrast: Cognitive and Discourse Perspectives, 257-281. Berlin: Mouton de Gruyter.

Sériot Patrick, 2007, Généraliser l'unique : genres, types et sphères chez Bakhtine, Texto!, vol. XII, n³, 22 p.

Traugott, Elizabeth, C., 2009, Interactional contexts and emergence: A historical perspective, April 23-25 2009, Bristol conference.

Velmezova, Ekaterina, 2011, Le dialogue bakhtinien, entre nouveauté terminologique et obstacle épistémologique, Cahiers de praxématique 57, 31-50.

Voloshinov, Valentin Nikolaevich. 1973 [1929].Marxism and the philosophy of language. New York: Seminar Press.

Zenkine S., 2012, Jean-Paul Bronckart, Cristian Bota, Bakhtine démasqué, Cahiers du monde russe [En ligne], 52/4 | 2011, consulté le 13/03/2015. URL : http://monderusse.revues.org/7509

Zima, Elisabeth, Brône, Geert, Feyaerts, Kurt \& Sambre, Paul, 2009. "Ce n'est pas très beau ce que vous avez dit": Resonance activation in French parliamentary debates. Discours 4, 1-17.

XX, 2005. 
XX, 2007.

XXX and XXX, 2008.

$\mathrm{XX}, 2012$.

\begin{abstract}
The notion of dialogism can be defined as the orientation of discourse towards other instances of discourse. The Russian semiotician, Mikhail Bakhtin, in his research on this topic, focused on a specific dialogic relationship - the anticipated response of the recipient. In other words, as a speaker progresses through his/her own speech, he/she imagines the discursive reactions of his/her recipient. $\mathrm{He} / \mathrm{she}$ interacts dialogically with these reactions in order firstly to reply in advance to questions and objections the recipient might formulate and secondly to rectify any fallacious conclusions that he/she might draw.

The purpose of the present article is to analyse this dialogic relationship, which we call anticipative interlocutive dialogism, specifically in order to describe the linguistic markers through which it is realised. We shall distinguish three linguistic forms of anticipative interlocutive dialogism according to the way the "anticipated reply" ascribed to the recipient is treated: prolepsis, integration, ellipsis.
\end{abstract}

